
\title{
$\angle$ Research Square \\ Early ART-initiation Reduces HIV-1 Proviral DNA Levels in Children from the CHER Trial
}

Helen Payne ( $\square$ helenpayne@doctors.org.uk)

Imperial College London - St Mary's Campus https://orcid.org/0000-0002-7083-9384

\section{Man Chan}

Department of pathology, University of Cape Town and National Health laboratory service

\section{Sarah Watters}

University College London

Kennedy Otwombe

Faculty of Health Sciences, University of the Witwatersrand

\section{Yuan Hsiao}

Department of pathology, University of Cape Town and National Health laboratory service

Abdel Babiker

MRC Clinical Trials Unit at University College London

\section{Avy Violari}

Faculty of Health Sciences, University of the Witwatersrand

\section{Mark Cotton}

Department of Paediatrics and Child Health, Stellenbosch University

\section{Diana Gibb}

MRC Clinical Trials Unit at University College London

\section{Nigel Klein}

Institute of Child Health, University College London

\section{Research}

Keywords: HIV-1 proviral DNA, children, reservoir, ART, CHER

Posted Date: April 6th, 2021

DOI: https://doi.org/10.21203/rs.3.rs-389348/v1

License: (9) This work is licensed under a Creative Commons Attribution 4.0 International License. Read Full License 


\section{Abstract}

BACKGROUND: Reduction of the reservoir of latent HIV-infected cells might increase the possibility of long-term remission in individuals living with HIV. We investigated factors associated with HIV-1 proviral DNA levels in children receiving different antiretroviral therapy (ART) strategies in the Children with HIV Early Antiretroviral Therapy (CHER) trial.

METHODS: Infants with HIV $<12$ weeks old with CD $4 \% \geq 25 \%$ were randomized in the CHER trial to early limited ART for 40 or 96 weeks (ART-40W, ART-96W), or deferred ART (ART-D ef). For ART-Def infants or following ART interruption in ART-40W/ART-96W, ART was started/re-started for clinical progression or CD4\% < 25\%. In 229 participants, HIV-1 proviral DNA was quantified by PCR from stored peripheral blood mononuclear cells from children who had received $\geq 24$ weeks ART and two consecutive undetectable HIV-1 RNA 12-24 weeks apart. HIV-1 proviral DNA was compared between ART-Def and ART-96W at week 96, and in all arms at week 248. Factors associated with HIV-1 proviral DNA levels were evaluated using linear regression.

FINDINGS: Longer duration of ART was significantly associated with lower HIV-1 proviral DNA at both 96 $(p=0.0003)$ and 248 weeks $(p=0.0011)$. Higher total CD 8 count at ART initiation was associated with lower HIV-1 proviral DNA at both $96(p=0.0225)$ and 248 weeks $(p=0.0398)$. Week 248 HIV-1 proviral DNA was significantly higher in those with positive HIV-1 serology at week 84 than those with negative serology $(p=0.0042)$.

INTEPRETATION: Longer ART duration is key to HIV-1 proviral DNA reduction. Further understanding is needed of the effects of "immune-attenuation" through early HIV-1 exposure.

FUNDING: Wellcome Trust, National Institutes of Health, Medical Research Council.

\section{Introduction:}

An estimated 3.3 million children under 15 years of age live with Human Immunodeficiency Virus (HIV) worldwide, over $90 \%$ in sub-Saharan Africa[1, 2]. The introduction of antiretroviral therapy (ART) early in life has substantially reduced morbidity and mortality $[3,4]$ and optimised CD 4 cell reconstitution[5]. Although HIV-1 virological suppression is achievable in most children, as in adults, HIV remains latent and integrated within the host genome in subpopulations of infected cells[6]. This reservoir, commonly estimated by quantitative measures of HIV-1 proviral DNA[7, 8], occurs in many cell types including CD34 stem cells, CNS macrophages, astrocytes and dendritic cells[9-11]: however resting CD4 memory cells are considered a critical reservoir due to their longevity, homeostatic cell division and potential for reactivation on antigen encounter[12].

There is increasing interest in viral reservoirs following reports of HIV remission (also known as functional cure) in adults and children treated soon after infection[13]. Remission is defined as lack of detectable virus in blood and a functional immune system without the need for ART, despite detectable 
HIV using sensitive assays. The case report of the "Mississippi Baby" who received ART from 31 hours of age focused attention on very early ART in children. The mother discontinued ART around 15-18 months of age and when retested at 23 months old, the infant had undetectable plasma HIV-RNA and only traces of proviral DNA just above detectable limits at 24 and 26 months of age. The infant maintained virological suppression for 27.6 months before viral resurgence[14, 15]. One of 227 early-treated children from the Children with HIV Early antiRetroviral therapy (CHER) trial, as per trial randomization, stopped ART after 40 weeks and remained negative for HIV diagnostic tests at the age of 9.5 years[16]. Virus persists at very low levels in the plasma and is detectable as low levels of cell-associated DNA, but immunologically he is not unlike healthy children of similar age.

Novel approaches to attain HIV remission, including depletion of T-cell subsets known to have integrated HIV-1 DNA, elimination of latent reservoir through activation and clearance mechanisms, and interference with memory CD4 T-cell homeostasis are being pursued $[12,17,18]$. However, as these are not presently considered viable options, early ART initiation remains the therapeutic focus.

Formation and stability of the HIV-1 reservoir in the presence of ART is not well understood[19-21], particularly whether its persistence is primarily due to longevity of latently infected cells or low-level replication[22-24]. Although earliest possible ART initiation is considered optimal in vertically infected children[25], it is unclear how timing of initiation, ART duration or ART-interruption within early childhood years, impacts on viral reservoirs and immune responses[26]. Further knowledge in these areas could inform practical approaches towards functional cure; yet even in the absence of a functional cure, the long-term impact of different ART-strategies on reservoir size is of considerable interest with potential to inform future ART management strategies in childhood.

In this sub-study of the CHER trial[3, 4], we compare peripheral HIV-1 proviral DNA in children who received early limited ART versus deferred ART. We examine the effect of ART-interruption and factors associated with low HIV-1 proviral DNA.

\section{Materials And Methods:}

\section{Participants}

The CHER trial compared early limited ART (zidovudine, lamivudine and lopinavir-ritonavir) for 40 or 96 weeks (ART-40W or ART-96W) with deferred ART (ART-Def) in HIV-infected infants $<12$ weeks old with baseline CD $4 \geq 25 \%[3,4]$ enrolled between $2005-2008$. HIV was diagnosed by HIV DNA PCR and confirmed with RNA viral load $(\mathrm{VL})>1000$ copies/ml. For Infants on deferred ART or following ART interruption after 40 or 96 weeks, ART was started/re-started for clinical progression (protocol-defined CDC severe stage $B / C$ disease) or $C D 4 \%<25 \%$ in infants and $<20 \%$ in older children.

HIV-1 proviral DNA was measured by quantitative PCR using DNA extracted from 322 samples of cryopreserved peripheral blood mononuclear cells (PBMCs) collected at 12-weekly time-points from 40248 weeks of the trial in 229 participants (Table 1). The use of stored samples was approved by the 
Human Research Ethics Committees of Stellenbosch University and the University of the Witwatersrand (M12/01/005 and 040703) for the two trial sites: Children's Infectious Disease Clinical Research Unit (now the Family Center for Research with Ubuntu) and The Perinatal HIV Research Unit (PHRU). To minimise inclusion of episomal DNA, samples were restricted to those available from all children on ART who were virally suppressed for at least 24 weeks with two consecutive viral loads below 400 copies $/ \mathrm{ml}$ 12-24 weeks apart[27]. In addition, children must have adhered to the CHER ART-strategies. Using these criteria, all available specimens were used from trial weeks 40 (ART-96W only), weeks 96 (ART-Def and ART-96W) and week 248 (all arms). Children from ART-Def who fulfilled these criteria at 3 or 4 time-points on continuous ART $(96,156,204,248$ and 252 weeks) were also analysed. Together these samples were used to answer the following questions: (1) What factors are associated with low levels of HIV-1 proviral DNA at 96 and 248 weeks of ART? (2) What is the effect of early ART followed by interruption on HIV-1 proviral DNA levels at 248 weeks compared to deferred ART without interruption i.e. comparing all CHER ART-strategies: ART-Def, ART-40W and ART-96W?

We explored the relationship between HIV-1 proviral DNA and clinical and immunological characteristics available from the CHER trial, including baseline (randomisation) viral loads, CMV serostatus and quantification at randomisation, and HIV-1 serostatus and quantitative HIV-specific antibodies (antigp120 lgG at week 84 in ART-Def and ART-96W[28]) at trial week 84. Week 84 was the closest available timepoint to week 96 where serum samples were available for analysis from children on ART[28].

\section{DNA extraction of PBMCs}

PBMCs were isolated from whole blood using standard Ficoll separation and cryopreserved in liquid nitrogen in $10 \%$ dimethyl sulfoxide and $90 \%$ fetal calf serum. Cryopreserved PBMCs were thawed to room temperature and DNA extracted using the QIAGEN® QIAmp DNA extraction kit (Hilden, Germany). Extracted DNA was eluted from the mini spin column, quantified on the nanodrop (Thermo Scientific, Massachusetts, USA), and stored at $-20^{\circ} \mathrm{C}$ until PCR.

\section{Quantification of total HIV-1 DNA}

As described by Smith et al[29], primers and probe were used to detect total HIV-1 DNA by amplifying the region between LTR and gag. Additionally, primers and probe for human pyruvate dehydrogenase (PDH) were duplexed in the reaction as an internal control. A standard curve was generated using a 6-point logarithmic scale of DNA extracted from $8 \mathrm{E} 5$ cells[30] (ATCC), which contain one copy of HIV provirus per cell.

HIV-1 proviral DNA was quantified by real-time PCR using Applied Biosystems 7900HT Fast Real-Time PCR System (TaqMan, Life technologies). For each $25 \mu \mathrm{l}$ PCR reaction the assay included $12.5 \mu \mathrm{l}$ of QIAgen Multiplex PCR Master Mix, $0.25 \mu$ of each primer PDH or LTR (concentration $10 \mu \mathrm{M}$ or $20 \mu \mathrm{M}$ ), and $0.25 \mu \mathrm{l}$ of each PDH and LTR probe at a concentration of $10 \mu \mathrm{M}$. PCR conditions were $95^{\circ} \mathrm{C}$ for 15 minutes, then 45 cycles of $94^{\circ} \mathrm{C}$ and $60^{\circ} \mathrm{C}$ for 1 minute each. To maximize assay sensitivity, $600 \mathrm{ng}$ of extracted DNA from patient samples was added to each reaction well, with both samples and standards run in 
triplicate. The lowest limit of detection was 10 proviral copies per $10^{6}$ PBMCs. Undetectable measures of proviral DNA were repeated for verification.

\section{Statistical analysis}

HIV-1 proviral DNA levels were log to base 10 transformed to approximate normality. Factors associated with log10 HIV-1 proviral DNA levels at weeks 96 and 248 were investigated using linear regression. Regression diagnostics were examined to ensure that all model assumptions were met.

Factors investigated included age at ART start, birthweight, sex, duration of ART by weeks 96 and 248, CDC stage, initial ART regimen, baseline VL and immunological data (CD4\% and count, CD8\% and count), time to initial VL suppression, CMV serology, child and mother PMTC, HIV-specific antibody (anti-gp120 $\operatorname{lgG}$ ) and HIV-1 serology measured at week 84 . Variables significantly associated with $\log _{10}$ HIV-1 proviral DNA levels at $p<0.10$ were included in a multivariable model, using backwards stepwise elimination (exit probability $p=0.05$ ) to reach the final model. Differences between two and three groups were tested using the Wilcoxon rank-sum and Kruskal-Wallis rank tests, respectively. Stata version 15.1 (Stata Corporation, College Station, Texas, USA) was used for all analyses.

\section{Results:}

To compare HIV-1 proviral DNA levels between early and deferred ART we analysed 44 PBMC samples from 125 children randomised to ART-Def (35.2\%), and 73 samples from 143 children in ART-96W (51\%) at 96 weeks. To compare HIV-1 proviral DNA levels across all three arms we analysed 70 PBMC samples from 125 children randomised to ART-Def (56\%), 56 samples from 143 children from ART-40W (39\%), and 43 samples from 143 children from ART-96W (30\%) at 248 weeks (Table 1).

\section{Factors associated with low levels of HIV-1 proviral DNA}

Time spent on ART by week 96 was significantly shorter in ART-Def (median 84 [IQR 72-84] weeks) versus ART-96W (96 [IQR 96-96], p < 0.0001). There was significantly more HIV-1 proviral DNA in ART-Def at 96 weeks (median 2415 [IQR 499-7450]) than ART-96W (325 [53-3670] copies of HIV-1 proviral DNA $/ 10^{6}$ PBMCs, $p=0.0019$, Fig. $1 \mathrm{~A}$ and 1B). In multivariable analysis (Table 4a), at 96 weeks, longer duration of $A R T$, or earlier age of starting ART, was significantly associated with lower levels of HIV-1 proviral DNA ( $\beta=-1.21(95 \% \mathrm{Cl}:-1.85,-0.57), p=0.0003)$. This suggests a reduction in HIV-1 proviral DNA percentage by $70 \%$ for every further year on ART. The same effect is evident at 248 trial weeks (Table $4 \mathrm{~b}$ ) whereby a reduction of $30 \% \mathrm{HIV}-1$ proviral DNA is seen for every further year on ART $(\beta=-0.36(95 \% \mathrm{Cl}$ : $-0.15,-0.15), p=0.0011)$. Figures $1 \mathrm{D}$ and $1 \mathrm{E}$ illustrate the spread of the data and how some individuals have high HIV-1 proviral DNA despite long duration of ART or viral load suppression.

Higher total CD8 count at ART initiation was associated with lower HIV-1 proviral DNA at both 96 and 248 weeks ( $\beta=-0.08$ (95\% Cl: $-0.14,-0.01), p=0.0225$ and $\beta=-0.07$ (95\% Cl: $-0.14,-0.00), p=0.0398$, respectively). 
Therefore, for every 500 cell increase in total CD8 count, a reduction of approximately $7 \%$ in HIV- 1 proviral DNA was demonstrated at weeks 96 and 248.

Compared to CDC stage $\mathrm{N}$ at enrolment, CDC stage $\mathrm{B}$ was associated with a $57 \%$ reduction in $\mathrm{HIV}-1$ proviral DNA levels at 96 weeks $(\beta=-0.84(95 \% \mathrm{Cl}:-1.58,-0.09), p=0.0287)$. This relationship was not seen at 248 weeks. There was $40 \%$ more reduction of HIV-1 proviral DNA levels at KIDCRU, the Cape Town trial study site compared to PHRU, the Johannesburg study site $(\beta=-0.52(95 \% \mathrm{Cl}:-0.85,-0.18), p=0.0031)$ at 248 weeks (but not 96 weeks). Multivariable analysis did not suggest that the different maternal or child PMTCT used at the two trial sites significantly affected total HIV-1 proviral DNA at either week 96 or 248.

At 248 weeks, HIV-1 proviral DNA levels were significantly higher in those with positive HIV-1 serology determined at 84 weeks compared to children with negative HIV-1 serology ( $\beta=0.73$ (95\% Cl: $0.23,1.22)$, $p=0.0042$ ). The same relationship was evident between undetermined serology (not determined in 56 ART-40W, 9 ART-96W and 19 ART-Def children) and increased HIV-1 proviral DNA levels compared with negative HIV-1 serology.

\section{Effect of ART interruption on HIV-1 proviral DNA}

The effect of time off ART in the first (ART-Def, $n=70$ ), second (ART-40W, $n=56$ ) or third (ART-96W, $n=43$ ) year of life was assessed by comparing HIV-1 proviral DNA between the treatment strategies at 248 weeks. In the children examined, the total time spent on ART from enrolment until 248 weeks was higher in ART-Def (median 228 [IQR 211,240] weeks, 220 [196,235] for ART-40W, 216 [168,247] for ART-96W; $p=$ 0.0001), as was the duration of viral load suppression (median 200 [IQR 163,214] weeks for ART-Def, 163 $[110,192]$ for ART-40W, $164[108,200]$ for ART-96W; $p=0.0001)$. There was no significant difference at 248 weeks between the 3 arms in HIV-1 proviral DNA (median 1165 [IQR 167,10900] HIV-1 proviral DNA/10 6 PBMCs for ART-Def, 4165 [294,26150] for ART-40W, 915 [172,15400] for ART-96W; $p=0.2553$, Fig. 1C).

Of the 229 children studied, only 2 children had HIV- 1 proviral DNA measurements $\leq 50$ copies/ $10^{6}$ PBMCs: 1 child from ART-Def with undetectable proviral DNA at 252 weeks and 1 child from ART-96W with HIV-1 proviral DNA 6 copies $/ 10^{6}$ PBMCs at 96 weeks.

\section{Discussion:}

Our study is currently the largest analysis of HIV-1 proviral DNA data from a randomized controlled trial in children and demonstrated that HIV-1 proviral DNA was significantly lower after 96 weeks of ART in children who started early ART than those with ART deferred until clinically or immunologically indicated. In multivariable analyses, longer duration of ART was significantly associated with lower levels of HIV-1 proviral DNA at both weeks 96 and 248, thus supporting the results from similar but smaller studies[3138].

The effect of duration of HIV infection and age of ART initiation on HIV-1 proviral DNA levels cannot be distinguished, since these two variables are intrinsically related. Also, it is not possible to determine the 
exact timing of infection, which can be either in utero, intrapartum or after birth. There is an inherent selection bias as more children died in ART-Def than early treated arms, none of whom had samples available for evaluation. Clinically unwell children may also have been less likely to have an aliquot of PBMCs or plasma stored. However, these biases most likely underestimate the associations seen as unwell children are more likely to have uncontrolled HIV-1 with potentially higher proviral DNA levels. This is reflected by the fact that the greater reduction in HIV-1 proviral DNA in children with CDC Stage $B$ at ART initiation may be due to having higher levels of integrated HIV-1 DNA before starting ART due to more advanced disease. Due to the nature of the HIV-1 proviral DNA assay measuring total HIV-1 proviral DNA, i.e. both integrated and episomal LTR, it was essential that children were virally suppressed for at least 12 weeks and therefore it was not possible to measure baseline proviral DNA in these children.

There was no significant difference in HIV-1 proviral DNA at 248 weeks between the 3 trial arms, suggesting the beneficial effect on reservoir reduction through early ART may be lost with treatment interruption, as reflected by other smaller studies[39, 40]; yet equally how continuous ART may counteract the detrimental effect of delayed ART initiation compared to early-ART followed by interruption. Subsequent analysis from a small group of children who did not interrupt early ART in the CHER trial demonstrated lower cell-associated HIV-1 DNA and RNA at 7-8 years of age in those that started ART before 2 months of age compared to after 2 months of age[38]. Furthermore, earlier initiation of continuous ART e.g. within the first week of life, has been associated with more rapid HIV-1 DNA decay compared to ART-initiation at medium of 7 weeks of age followed by ART-interruption (ART-96W) and ARTinitiation at medium 22 weeks followed by continuous ART (ART-Def)[40, 41].

HIV-1 seropositivity at 84 weeks was associated with higher proviral DNA at 248 weeks, however quantitative HIV-1 anti-gp120 antibody levels did not show this relationship[28], although when applying a wider range of HIV-specific antibodies has since demonstrated to estimate reservoir size[42]. While duration of ART is clearly a key determinant of the viral reservoir, we observed individual children with high HIV-1 proviral DNA levels despite long-term ART and RNA suppression. This has been described previously $[43,44]$ and might be explained by longer periods of intra-uterine infection, and possibly interval viral load testing not capturing "viral blips". It may also be due to homeostatic proliferation of HIV-infected cells in the absence of viral reactivation[45, 46], although this has not been demonstrated in peripheral blood mononuclear cells[47]. Despite virological control with ART, persistent inflammation and immune activation is recognized in perinatally-acquired HIV[48, 49], potentially driving proliferation of cells that harbor latent integrated HIV[12] such as within follicular B-cells[50, 51].

Higher CD8 count at ART initiation was associated with a greater reduction in HIV-1 proviral DNA. This may reflect a functional immune response to HIV-infection, implying that the dynamics of reservoir decline may not be solely reliant on adequate viral suppression, but the stability of viral proteins such as reverse transcriptase, tat and gp41[52]. In response to HIV, total levels of CD8 increase from a combination of thymic output of naïve CD8 T-cells and proliferation via clonal expansion. This may be regarded as "immune-attenuation" and suggests that alongside ART, CD8 T-cells may play an important role in controlling HIV infection and potentially mediate eradication of viral reservoirs of infection through 
interaction with various HLA types such as HLA-B*27:02 [53]. The vast majority of children had viral loads from enrolment reported as $>750,000 \mathrm{copies} / \mathrm{ml}$ therefore we are unable to determine whether a relationship exists between higher viral loads and higher CD8 counts.

A site effect was observed as children in Cape Town had significantly lower levels of HIV-1 proviral DNA at week 248 than in Soweto. This may reflect variation in clinician approach to starting or re-starting ART or regional differences in PMTCT at that time (2004-2006) prior to the era of Option B Plus[54].

\section{Conclusions:}

Our study affirms the association between longer duration of ART and reduced levels of HIV-1 proviral DNA in children. We also demonstrated associations between higher CD8 count at ART initiation with greater reduction of HIV-1 proviral DNA, inferring a possible beneficial effect of early HIV-1 viral exposure and "immune-attenuation" alongside ART. While we have analysed multiple factors, there are other factors that have not been examined that may plausibly influence levels of HIV-1 proviral DNA: timing of HIV-transmission and initial maternal viral burden, ART adherence, co-infections, thymic output and immune activation. Further work is required to better understand these dynamics and identify potential targets for adjunctive HIV-1 reduction strategies, now a major approach for reducing HIV reservoirs as children become adults.

\section{Declarations:}

Ethics approval and consent to participate: The use of stored samples was approved by the Human Research Ethics Committees of Stellenbosch and Witwatersrand Universities (M12/01/005 and 040703) where the CHER trial was conducted at their respective trial sites: Family Center for Research with Ubuntu (FAMCRU) and The Perinatal HIV Research Unit (PHRU).

Consent for publication: This manuscript does not contain any individual person's data in any form (including any individual details, images or videos), therefore consent for publication is not applicable.

Availability of data and materials: The datasets used and/or analysed during the current study are available from the corresponding author on reasonable request.

Competing interests: There are no financial and non-financial competing interests to be declared.

Funding: This study was funded by The Wellcome Trust, and The CHER trial, collection and storage of samples and data was funded by The US National Institute ofAllergy and Infectious Diseases (NIAID).

Authors' contributions: HP, NJK and DMG conceived the study. AV and MFC were the protocol co-chairs for each site of the CHER trial. KO provided the specimens and necessary data from the CHER trial. SW established and taught the assay to HP. HP processed the specimens. MC performed the statistical analysis with assistance from $A B$. NYH processed the specimens for CMV DNA. NJK, DMG, AB, AV, MFC 
and RC contributed to the study design and data interpretation. HP prepared the manuscript. Professor Robin Callard (RC) sadly passed away before completion of the manuscript. All authors contributed to writing the manuscript and approved the final draft for submission.

Acknowledgements: We are grateful to all the children and their families who participated in the CHER trial, the staff at the Perinatal Research Unit and the Children's Infectious Disease Clinical Research Unit for performing the trial, Wendy Stevens at Clinical Laboratory Services for sample storage, and Lynn Morris at the National Institute for Communicable Diseases for her support in the quantitative HIVantibody work. We also thank Gerhard Walzl and the Stellenbosch Immunology Group for laboratory infrastructure and support.

\section{References:}

1. UNAIDS, UNAIDS REPORT ON THE GLOBAL AIDS EPIDEMIC. 2010. "UNAIDS/10.11E | JC1958E".

2. Maartens G, et al. HIV infection: epidemiology, pathogenesis, treatment, and prevention. Lancet, 2014. 384(9939):258-71.

3. Cotton, M.F., et al., Early time-limited antiretroviral therapy versus deferred therapy in South African infants infected with HIV: results from the children with HIV early antiretroviral (CHER) randomised trial. Lancet, 2013. 382(9904): p. 1555-63.

4. Violari A, et al, Early antiretroviral therapy and mortality among HIV-infected infants. N Engl J Med, 2008. 359(21): p. 11.

5. Lewis, J., et al., Age and CD4 count at initiation of antiretroviral therapy in HIV-infected children: effects on long-term T-cell reconstitution. The Journal of infectious diseases, 2012. 205(4): p. 54856.

6. Suspene, R. and A. Meyerhans, Quantification of unintegrated HIV-1 DNA at the single cell level in vivo. Plos one, 2012. 7(5): p. e36246.

7. De Rossi, A., et al., Quantitative HIV-1 proviral DNA detection: a multicentre analysis. The new microbiologica, 2010. 33(4): p. 293-302.

8. Zhao, Y., et al., Quantification of human immunodeficiency virus type 1 proviral DNA by using TaqMan technology. Journal of clinical microbiology, 2002. 40(2): p. 675-8.

9. Finzi, D., et al., Identification of a reservoir for HIV-1 in patients on highly active antiretroviral therapy. Science, 1997. 278(5341): p. 1295-300.

10. Sleasman, J.W., et al., CD4+ memory T cells are the predominant population of HIV-1-infected lymphocytes in neonates and children. AIDS, 1996. 10(13): p. 1477-84.

11. Alexaki, A., et al, Cellular reservoirs of HIV-1 and their role in viral persistence. Current HIV research, 2008. 6(5): p. 388-400.

12. Chomont, N., et al., HIV reservoir size and persistence are driven by T cell survival and homeostatic proliferation. Nature medicine, 2009. 15(8): p. 893-900. 
13. Saez-Cirion, A., et al., Post-treatment HIV-1 controllers with a long-term virological remission after the interruption of early initiated antiretroviral therapy ANRS VISCONTI Study. PLoS pathogens, 2013. 9(3): p. e1003211.

14. Luzuriaga, K., et al., Viremic relapse after HIV-1 remission in a perinatally infected child. The New England journal of medicine, 2015. 372(8): p. 786-8.

15. Persaud, D. and K. Luzuriaga, Absence of HIV-1 after treatment cessation in an infant. The New England journal of medicine, 2014. 370(7): p. 678.

16. Violari, A., et al., A child with perinatal HIV infection and long-term sustained virological control following antiretroviral treatment cessation. Nat Commun, 2019. 10(1): p. 412.

17. Battistini, A. and M. Sgarbanti, HIV-1 latency: an update of molecular mechanisms and therapeutic strategies. Viruses, 2014. 6(4): p. 1715-58.

18. Archin, N.M., et al., Expression of latent HIV induced by the potent HDAC inhibitor suberoylanilide hydroxamic acid. AIDS research and human retroviruses, 2009. 25(2): p. 207-12.

19. Chun, T.W., et al., Rebound of plasma viremia following cessation of antiretroviral therapy despite profoundly low levels of HIV reservoir: implications for eradication. AIDS, 2010. 24(18): p. 2803-8.

20. Chun TW, et al., Presence of an inducible HIV-1 latent reservoir during highly active antiretroviral therapy. . Proc Natl Acad Sci USA., 1997. 94,: p. 13193-7.

21. Palmer S, et al, Low-level viremia persists for at least 7 years in patients on suppressive antiretroviral therapy. . Proc Natl Acad Sci USA., 2008. 105: p. 3879-84.

22. Natarajan, V., et al., HIV-1 replication in patients with undetectable plasma virus receiving HAART. Highly active antiretroviral therapy. Lancet, 1999. 353(9147): p. 119-20.

23. Ramratnam, B., et al., The decay of the latent reservoir of replication-competent HIV-1 is inversely correlated with the extent of residual viral replication during prolonged anti-retroviral therapy. Nature medicine, 2000. 6(1): p. 82-5.

24. Hatano, $\mathrm{H}$., et al., Increase in 2-long terminal repeat circles and decrease in D-dimer after raltegravir intensification in patients with treated HIV infection: a randomized, placebo-controlled trial. The Journal of infectious diseases, 2013. 208(9): p. 1436-42.

25. Persaud, D., et al., Influence of Age at Virologic Control on Peripheral Blood Human Immunodeficiency Virus Reservoir Size and Serostatus in Perinatally Infected Adolescents. JAMA pediatrics, 2014.

26. Zanchetta, M., et al., Early therapy in HIV-1-infected children: effect on HIV-1 dynamics and HIV-1specific immune response. Antiviral therapy, 2008. 13(1): p. 47-55.

27. Murray, J.M., et al., Integrated HIV DNA accumulates prior to treatment while episomal HIV DNA records ongoing transmission afterwards. AIDS, 2012. 26(5): p. 543-50.

28. Payne, H., et al., Reactivity of routine HIV antibody tests in children who initiated antiretroviral therapy in early infancy as part of the Children with HIV Early Antiretroviral Therapy (CHER) trial: a retrospective analysis. The Lancet Infectious Diseases, 2015. 
29. Smith, N.M., et al., Proof-of-Principle for Immune Control of Global HIV-1 Reactivation In Vivo. Clinical infectious diseases : an official publication of the Infectious Diseases Society of America, 2015. 61(1): p. 120-8.

30. Folks, T.M., et al., Biological and biochemical characterization of a cloned Leu-3-cell surviving infection with the acquired immune deficiency syndrome retrovirus. The Journal of experimental medicine, 1986. 164(1): p. 280-90.

31. Ananworanich, J., et al., Reduced markers of HIV persistence and restricted HIV-specific immune responses after early antiretroviral therapy in children. AIDS, 2014. 28(7): p. 1015-20.

32. Luzuriaga, K., et al., Reduced HIV Reservoirs After Early Treatment HIV-1 Proviral Reservoirs Decay Continously Under Sustained Virologic Control in Early-Treated HIV-1-Infected Children. The Journal of infectious diseases, 2014.

33. Persaud, D., et al., Dynamics of the resting CD4(+) T-cell latent HIV reservoir in infants initiating HAART less than 6 months of age. AIDS, 2012. 26(12): p. 1483-90.

34. Martinez-Bonet, M., et al., Establishment and Replenishment of the Viral Reservoir in Perinatally HIV1-infected Children Initiating Very Early Antiretroviral Therapy. Clinical infectious diseases : an official publication of the Infectious Diseases Society of America, 2015. 61(7): p. 1169-78.

35. Tagarro A, et al, Early and Highly Suppressive Antiretroviral Therapy Are Main Factors Associated With Low Viral Reservoir in European Perinatally HIV-Infected Children. J Acquir Immune Defic Syndr., 2018. Oct 1;79(2):269-276.(doi: 10.1097/QAI.0000000000001789. ).

36. Kuhn L, et al. Age at antiretroviral therapy initiation and cell-associated HIV-1 DNA levels in HIV-1infected children. . Plos One., 2018. Apr 12;13(4):e0195514.

37. Foster C, et al, Early antiretroviral therapy reduces HIV DNA following perinatal HIV infection. AIDS, 2017. Aug 24;31(13):1847-1851. .

38. van Zyl, G.U., et al., Early Antiretroviral Therapy in South African Children Reduces HIV-1-Infected Cells and Cell-Associated HIV-1 RNA in Blood Mononuclear Cells. J Infect Dis, 2015. 212(1): p. 39-43.

39. Pankau MD, at al, Decay of HIV DNA in the Reservoir and the Impact of Short Treatment Interruption in Kenyan Infants. . Open Forum Infect Dis, 2017. Dec 9;5(1):ofx268. .

40. Veldsman, K.A., et al., HIV-1 DNA decay is faster in children who initiate ART shortly after birth than later. J Int AIDS Soc, 2019. 22(8): p. e25368.

41. Veldsman, K.A., et al., Rapid decline of HIV-1 DNA and RNA in infants starting very early antiretroviral therapy may pose a diagnostic challenge. AIDS, 2018. 32(5): p. 629-634.

42. Rocca, S., et al., Human Immunodeficiency Virus (HIV)-Antibody Repertoire Estimates Reservoir Size and Time of Antiretroviral Therapy Initiation in Virally Suppressed Perinatally HIV-Infected Children. J Pediatric Infect Dis Soc, 2019. 8(5): p. 433-438.

43. Zanchetta, M., et al., Long-term decay of the HIV-1 reservoir in HIV-1-infected children treated with highly active antiretroviral therapy. The Journal of infectious diseases, 2006. 193(12): p. 1718-27. 
44. Palma, P., et al., The HIV-1 antibody response: a footprint of the viral reservoir in children vertically infected with HIV. Lancet HIV, 2020. 7(5): p. e359-e365.

45. Bosque, A., et al., Homeostatic proliferation fails to efficiently reactivate HIV-1 latently infected central memory CD4+ T cells. PLoS pathogens, 2011. 7(10): p. e1002288.

46. Reeves, et al. A majority of HIV persistence during antiretroviral therapy is due to infected cell proliferation. Nature Communications., 2018. Nov 16;9(1):4811.

47. Van Zyl, G.U., et al., No evidence of HIV replication in children on antiretroviral therapy. J Clin Invest, 2017. 127(10): p. 3827-3834.

48. Eckard, A.R., et al., Neurocognitive dysfunction in HIV-infected youth: investigating the relationship with immune activation. Antivir Ther, 2017. 22(8): p. 669-680.

49. Eckard, A.R., et al., Increased Immune Activation and Exhaustion in HIV-infected Youth. Pediatr Infect Dis J, 2016. 35(12): p. e370-e377.

50. Sung JM, M.D., HIV Persistence on Antiretroviral Therapy and Barriers to a Cure. . Adv Exp Med Biol., 2018. 1075:165-185. .

51. Bronnimann, MP et al The B-Cell Follicle in HIV Infection: Barrier to a Cure. Front Immunol, 2018. 9: p. 20.

52. Burbelo, P.D., et al., HIV antibody characterization as a method to quantify reservoir size during curative interventions. The Journal of infectious diseases, 2014. 209(10): p. 1613-7.

53. Adland E, at al, Differential Immunodominance Hierarchy of CD8+ T-Cell Responses in HLA-B*27:05and $-B \star 27: 02-M e d i a t e d$ Control of HIV-1 Infection. J Virology, 2018. 30; 92 (4)(Jan).

54. Karnon J, et al, Option B+ for the prevention of mother-to-child transmission of HIV infection in developing countries: a review of published cost-effectiveness analyses. Health Policy Plan, 2016. Oct;31(8):1133-41.

\section{Tables:}

Table 1. PBMC sample availability 


\begin{tabular}{|lllll|}
\hline & ART-Def & ART-40W & ART-96W & Total \\
\cline { 2 - 5 } & N or N (\%) & & & \\
\hline Number of children & & & & \\
\hline Randomised into the main CHER trial & 125 & 143 & 143 & 411 \\
\hline Who died* & 21 & 14 & 12 & 47 \\
\hline Had samples available & 79 & 56 & 94 & 229 \\
\hline Number of samples available & & & & \\
\hline At week 96 & $44(29.3 \%)$ & - & $73(62.9 \%)$ & $117(36.3 \%)$ \\
\hline At week 156 & $13(8.7 \%)$ & - & - & $13(4.0 \%)$ \\
\hline At week 204 & $13(8.7 \%)$ & - & - & $13(4.0 \%)$ \\
\hline At week 248 & $70(46.7 \%)$ & $56(100 \%)$ & $43(37.1 \%)$ & $169(52.5 \%)$ \\
\hline At week 252 & $10(6.7 \%)$ & - & - & $10(3.1 \%)$ \\
\hline Total & $\mathbf{1 5 0}$ & $\mathbf{5 6}$ & $\mathbf{1 1 6}$ & $\mathbf{3 2 2}$ \\
\hline
\end{tabular}

*No samples were available from children who died

Table 2. Patient characteristics 


\begin{tabular}{|c|c|c|c|c|}
\hline & ART-Def & ART-40W & ART-96W & Total \\
\hline & \multicolumn{4}{|c|}{ Median (IQR) [N] or N (\%) } \\
\hline $\begin{array}{l}\text { Number of } \\
\text { patients }\end{array}$ & 79 & 56 & 94 & 229 \\
\hline $\begin{array}{l}\text { Age at } \\
\text { randomisation } \\
\text { (weeks) }\end{array}$ & $7.3(6.4,9.1)[79]$ & $7.9(7.3,9.2)[56]$ & $7.6(6.7,8.6)[94]$ & $7.6(6.7,9.0)[229]$ \\
\hline $\begin{array}{l}\text { Age at ART start } \\
\text { (weeks) }\end{array}$ & $\begin{array}{l}26.1(20.0,42.9) \\
{[79]}\end{array}$ & $7.9(7.3,9.2)[56]$ & $7.6(6.7,8.6)[94]$ & $\begin{array}{l}8.7(7.4,20.1) \\
{[229]}\end{array}$ \\
\hline Birthweight (Kg) & $2.9(2.6,3.3)[79]$ & $2.9(2.6,3.2)[56]$ & $3.0(2.7,3.3)[94]$ & $2.9(2.6,3.3)[229]$ \\
\hline \multicolumn{5}{|l|}{ Gender } \\
\hline Female & $49(62.0 \%)$ & $28(50.0 \%)$ & $52(55.3 \%)$ & $129(56.3 \%)$ \\
\hline Male & $30(38.0 \%)$ & $28(50.0 \%)$ & $42(44.7 \%)$ & $100(43.7 \%)$ \\
\hline \multicolumn{5}{|l|}{ Ethnic origin } \\
\hline Black & $79(100.0 \%)$ & $52(92.9 \%)$ & $89(94.7 \%)$ & $220(96.1 \%)$ \\
\hline Non-black & $0(0.0 \%)$ & $4(7.1 \%)$ & $5(5.3 \%)$ & $9(3.9 \%)$ \\
\hline \multicolumn{5}{|l|}{ Infant PMTCT } \\
\hline No & $9(11.4 \%)$ & $5(8.9 \%)$ & $14(14.9 \%)$ & $28(12.2 \%)$ \\
\hline Yes & $67(84.8 \%)$ & 49 (87.5\%) & 77 (81.9\%) & $193(84.3 \%)$ \\
\hline Unknown & $3(3.8 \%)$ & $2(3.6 \%)$ & $3(3.2 \%)$ & $8(3.5 \%)$ \\
\hline \multicolumn{5}{|l|}{ Mother PMTCT } \\
\hline No & $10(12.7 \%)$ & $6(10.7 \%)$ & $10(10.6 \%)$ & $26(11.4 \%)$ \\
\hline Yes & $69(87.3 \%)$ & $50(89.3 \%)$ & $84(89.4 \%)$ & $203(88.6 \%)$ \\
\hline \multicolumn{5}{|l|}{ Clinical Site } \\
\hline KIDCRU & $24(30.4 \%)$ & $26(46.4 \%)$ & $29(30.9 \%)$ & 79 (34.5\%) \\
\hline PHRU & $55(69.6 \%)$ & $30(53.6 \%)$ & $65(69.1 \%)$ & $150(65.5 \%)$ \\
\hline \multicolumn{5}{|l|}{ CDC stage } \\
\hline A & $6(7.6 \%)$ & 19 (33.9\%) & $13(13.8 \%)$ & $38(16.6 \%)$ \\
\hline B & $4(5.1 \%)$ & $1(1.8 \%)$ & $6(6.4 \%)$ & $11(4.8 \%)$ \\
\hline $\mathrm{N}$ & 69 (87.3\%) & $36(64.3 \%)$ & 75 (79.8\%) & $180(78.6 \%)$ \\
\hline
\end{tabular}




\begin{tabular}{|c|c|c|c|c|}
\hline Negative & $49(62.0 \%)$ & $37(66.1 \%)$ & $64(68.1 \%)$ & $150(65.5 \%)$ \\
\hline Positive & $10(12.7 \%)$ & $11(19.6 \%)$ & $18(19.1 \%)$ & $39(17.0 \%)$ \\
\hline $\begin{array}{l}\text { No } \\
\text { sample/missing }\end{array}$ & $20(25.3 \%)$ & $8(14.3 \%)$ & $12(12.8 \%)$ & $40(17.5 \%)$ \\
\hline \multicolumn{5}{|l|}{$\begin{array}{l}\text { Viral load } \\
\text { (copies/ml) }\end{array}$} \\
\hline At randomisation & $\begin{array}{l}750001 \\
(501000,750001) \\
{[79]}\end{array}$ & $\begin{array}{l}557500 \\
(194000,750001) \\
{[56]}\end{array}$ & $\begin{array}{l}750001 \\
(645000,750001) \\
{[94]}\end{array}$ & $\begin{array}{l}750001 \\
(439000,750001) \\
{[229]}\end{array}$ \\
\hline At ART start & $\begin{array}{l}750001 \\
(142400,750001) \\
{[78]}\end{array}$ & $\begin{array}{l}557500 \\
(194000,750001) \\
{[56]}\end{array}$ & $\begin{array}{l}750001 \\
(645000,750001) \\
{[94]}\end{array}$ & $\begin{array}{l}750001 \\
(338000,750001) \\
{[228]}\end{array}$ \\
\hline \multicolumn{5}{|l|}{$\begin{array}{l}\log _{10} \text { Viral load } \\
\text { (copies/ml) }\end{array}$} \\
\hline At randomisation & $5.9(5.7,5.9)[79]$ & $5.7(5.3,5.9)[56]$ & $5.9(5.8,5.9)[94]$ & $5.9(5.6,5.9)[229]$ \\
\hline At ART start & $5.9(5.2,5.9)[78]$ & $5.7(5.3,5.9)[56]$ & $5.9(5.8,5.9)[94]$ & $5.9(5.5,5.9)[228]$ \\
\hline \multicolumn{5}{|l|}{$\begin{array}{l}\text { Immune related } \\
\text { features }\end{array}$} \\
\hline \multicolumn{5}{|l|}{ CD4\% } \\
\hline At screening & $37(31,42)[78]$ & $34(29,40)[56]$ & $36(31,42)[94]$ & $36(31,42)[228]$ \\
\hline At randomisation & $35(29,39)[75]$ & $35(30,41)[54]$ & $34(29,38)[89]$ & $35(29,39)[218]$ \\
\hline At ART start & $22(19,30)[78]$ & $35(30,41)[54]$ & $34(29,38)[89]$ & $31(25,37)[221]$ \\
\hline \multicolumn{5}{|l|}{ CD4 count } \\
\hline At screening & $\begin{array}{l}2543 \\
(1771,3062)[78]\end{array}$ & $\begin{array}{l}1955 \\
(1405,2431)[56]\end{array}$ & $\begin{array}{l}2242 \\
(1661,2995)[94]\end{array}$ & $\begin{array}{l}2225(1611,2986) \\
{[228]}\end{array}$ \\
\hline At randomisation & $\begin{array}{l}1968 \\
(1572,2542)[75]\end{array}$ & $\begin{array}{l}1918 \\
(1279,2555)[54]\end{array}$ & $\begin{array}{l}2002 \\
(1480,2762)[89]\end{array}$ & $\begin{array}{l}1956(1446,2688) \\
{[218]}\end{array}$ \\
\hline At ART start & $\begin{array}{l}1079(712,1495) \\
{[78]}\end{array}$ & $\begin{array}{l}1918 \\
(1279,2555)[54]\end{array}$ & $\begin{array}{l}2002 \\
(1480,2762)[89]\end{array}$ & $\begin{array}{l}1574(1103,2425) \\
{[221]}\end{array}$ \\
\hline \multicolumn{5}{|l|}{ CD8\% } \\
\hline At screening & $23(21,34)[77]$ & $28(20,34)[54]$ & $26(21,33)[93]$ & $26(21,34)[224]$ \\
\hline At randomisation & $25(21,33)[78]$ & $28(22,34)[54]$ & $27(22,34)[93]$ & $27(21,34)[225]$ \\
\hline At ART start & $34(29,43)[79]$ & $28(22,34)[54]$ & $27(22,34)[93]$ & $30(23,37)[226]$ \\
\hline \multicolumn{5}{|l|}{ CD8 count } \\
\hline At screening & 1589 & 1494 & 1648 & $1597(1135,2238)$ \\
\hline
\end{tabular}




\begin{tabular}{|lllll|} 
& $(1153,2480)[77]$ & $(1050,2026)[54]$ & $(1142,2243)[93]$ & {$[224]$} \\
\hline \multirow{2}{*}{ At randomisation } & 1416 & $1331(998,2025)$ & 1686 & $1471(1094,2258)$ \\
& $(1115,2227)[78]$ & {$[54]$} & $(1139,2386)[93]$ & {$[225]$} \\
\hline \multirow{2}{*}{ At ART start } & $1465(874,2454)$ & $1331(998,2025)$ & 1686 & $1530(1036,2294)$ \\
& {$[79]$} & {$[54]$} & $(1139,2386)[93]$ & {$[226]$} \\
\hline
\end{tabular}

Table 3. Follow-up 


\begin{tabular}{|c|c|c|c|c|}
\hline & ART-Def & ART-40W & ART-96W & Total \\
\hline & \multicolumn{4}{|c|}{ Median (IQR) [N] or N (\%) } \\
\hline \multicolumn{5}{|l|}{ Duration of ART (weeks)* } \\
\hline By week 96 & $84(72,84)[44]$ & - & $96(96,96)[73]$ & $96(84,96)[117]$ \\
\hline By week 248 & $\begin{array}{l}228(211,240) \\
{[70]}\end{array}$ & $\begin{array}{l}220(196,235) \\
{[56]}\end{array}$ & $\begin{array}{l}216(168,247) \\
{[43]}\end{array}$ & $\begin{array}{l}220(200,240) \\
{[169]}\end{array}$ \\
\hline \multicolumn{5}{|l|}{$\begin{array}{l}\text { Duration of viral } \\
\text { suppression (weeks) }\end{array}$} \\
\hline By week 248 & $\begin{array}{l}200(163,214) \\
{[70]}\end{array}$ & $\begin{array}{l}163(110,192) \\
{[56]}\end{array}$ & $\begin{array}{l}164(108,200) \\
{[43]}\end{array}$ & $\begin{array}{l}179(132,204) \\
{[169]}\end{array}$ \\
\hline Anti-gp120 lgG at week 84 & $\begin{array}{l}5208 \\
(812,24751) \\
{[60]}\end{array}$ & - & $\begin{array}{l}218(133,662) \\
{[87]}\end{array}$ & $\begin{array}{l}420 \\
(169,13129) \\
{[147]}\end{array}$ \\
\hline \multicolumn{5}{|l|}{ HIV-1 serology at week 84} \\
\hline Negative & $8(10.1 \%)$ & $0(0 \%)$ & $41(43.6 \%)$ & 49 (21.4\%) \\
\hline Positive & $52(65.8 \%)$ & $0(0 \%)$ & $44(46.8 \%)$ & $96(41.9 \%)$ \\
\hline Not determined & $19(24.1 \%)$ & $56(100 \%)$ & $9(9.6 \%)$ & $84(36.7 \%)$ \\
\hline \multicolumn{5}{|l|}{ CD4\% } \\
\hline At week 96 & $35(31,40)[44]$ & $31(29,34)[2]$ & $37(31,42)[72]$ & $37(31,41)[118]$ \\
\hline At week 248 & $36(33,40)[70]$ & $34(29,39)[54]$ & $32(27,36)[43]$ & $35(30,39)[167]$ \\
\hline \multicolumn{5}{|l|}{ CD4 count (cells/ml) } \\
\hline At week 96 & $\begin{array}{l}1650 \\
(1244,2227) \\
{[44]}\end{array}$ & $\begin{array}{l}1696 \\
(1595,1797) \\
{[2]}\end{array}$ & $\begin{array}{l}1647 \\
(1131,2043) \\
{[72]}\end{array}$ & $\begin{array}{l}1650 \\
(1190,2063) \\
{[118]}\end{array}$ \\
\hline At week 248 & $\begin{array}{l}1175 \\
(885,1562) \\
{[70]}\end{array}$ & $\begin{array}{l}1110 \\
(866,1349) \\
{[54]}\end{array}$ & $\begin{array}{l}1039 \\
(755,1374) \\
{[43]}\end{array}$ & $\begin{array}{l}1115 \\
(866,1428) \\
{[167]}\end{array}$ \\
\hline \multicolumn{5}{|l|}{$\begin{array}{l}\text { HIV-1 DNA (copies } / 10^{6} \\
\text { PBMC) }\end{array}$} \\
\hline At week 40 & - & - & $\begin{array}{l}317(44,884) \\
{[8]}\end{array}$ & $317(44,884)[8]$ \\
\hline At week 96 & $\begin{array}{l}2415 \\
(499,7450) \\
{[44]}\end{array}$ & - & $\begin{array}{l}325(53,3670) \\
{[73]}\end{array}$ & $\begin{array}{l}681(106,5580) \\
{[117]}\end{array}$ \\
\hline At week 156 & $\begin{array}{l}2290 \\
(513,13700) \\
{[13]}\end{array}$ & - & - & $\begin{array}{l}2290 \\
(513,13700) \\
{[13]}\end{array}$ \\
\hline
\end{tabular}




\begin{tabular}{|lllll|}
\hline At week 204 & 625 & - & - & $625(175,2140)$ \\
& $(175,2140)$ & & & {$[13]$} \\
& {$[13]$} & & & \\
At week 248 & 1165 & 4165 & 915 & 1220 \\
& $(167,10900)$ & $(294,26150)$ & $(172,15400)$ & $(184,17300)$ \\
& {$[70]$} & {$[56]$} & {$[43]$} & {$[169]$} \\
\hline At week 252 & $58(18,129)$ & - & -- & $58(18,129)[10]$ \\
& {$[10]$} & & & \\
\hline
\end{tabular}

*Duration of ART by w96 was determined by calculating time from ART start to w96 HIV DNA measurement i.e. Duration of ART by w96 (Arm 1/3) = [w96 HIV DNA date - ART start date] days.

\section{*Duration of ART by w248 was determined as follows:}

- Arm 1: calculating time from ART start to w248 HIV DNA measurement i.e. Duration of ART by w248 (Arm 1) = [w248 HIV DNA date - ART start date] days.

- Arms 2 and 3: summing the time from ART start to ART interruption and time from ART restart to w248 HIV DNA measurement, i.e. Duration of ART w248 (Arm 2/3) = [ART interruption date - ART start date] + [w248 HIV DNA date - ART restart date] days.

\#Duration of VL suppression by w248 was calculated by summing all the periods of time $V L<400$ copies $/ \mathrm{ml}$. Single isolated VL spikes (i.e. VL $>=400$ copies $/ \mathrm{ml}$ ) preceded and followed by $\mathrm{VL}<400$ copies/ml were allowed and counted as VL suppressed.

Table 4. Factors associated with HIV-1 DNA levels at weeks 96 and 248. At w96, HIV-1 DNA was measured in 44 ART-Def and 73 ART-96W children. At w248, HIV-1 DNA was measured in 70 ART-Def, 56 ART-40W and 43 ART-96W arms. Factors significantly associated with HIV-1 DNA in univariable analyses were included in the multivariable (adjusted) analysis.

a) Factors associated with HIV-1 DNA at week 96 
Univariable model

\% change $\quad b(95 \% \mathrm{Cl})$ in HIV

DNA
Multivariable model

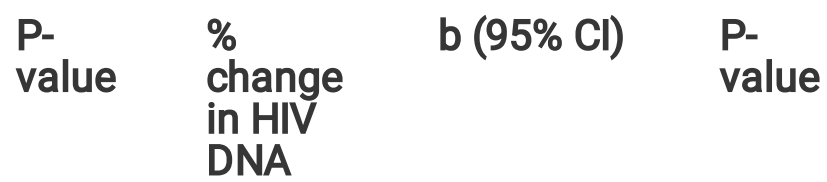

\section{At ART initiation}

Age (per month older) 11.12

0.11

0.0002

$(0.05,0.16)$

$\log _{10}$ viral load

$-2.27$

$-0.23$

0.2145

[copies/ml] (per 10\%

increase)

\section{Viral load}

$<750,000$ copies/ml

(Ref: $\geq 750,000$ )

12.57

0.12

$(-0.27,0.51)$

Time to VL

suppression (per

month longer)

2.30

0.02

$(-0.05,0.10)$

0.5504

Birthweight (per Kg

higher)

18.65

0.17

$(-0.29,0.63)$

CD4 count (per 500 cell $\quad-7.63$

increase)

$-0.08$

$(-0.16,0.00)$

CD4\% (per 10\%

increase)

$-10.90$

$-0.12$

$(-0.33,0.10)$

CD8 count (per 500 cell $\quad-7.19$

increase)

$-0.07$

$(-0.14,-0.01)$

0.5493

CD8\% (per 10\%

increase)

2.83

0.03

$(-0.14,0.20)$

0.4629

0.0549

0.2845

Gender

Male (Ref: Female)

$-6.62$

$-0.07$

$(-0.46,0.32)$

0.7282

$0.0346 \quad-7.28$

$-0.08$

$(-0.14,-0.01)$

0.0225

0.7471

\section{CDC stage}

$\begin{array}{lllllll}\text { A (Ref: N) } & -13.69 & -0.15 & 0.6414 & -2.51 & -0.03 & 0.9319 \\ & & (-0.77,0.48) & & & (-0.61,0.56) & \\ \text { B (Ref: N) } & -60.08 & -0.92 & 0.0247 & -56.64 & -0.84 & 0.0287 \\ & & (-1.72,-0.12) & & & (-1.58,-0.09) & \end{array}$

Site

KIDCRU (Ref: PHRU)

6.64

0.06

0.7660

$(-0.36,0.49)$ 


\section{Serology}

\begin{tabular}{lcll} 
Positive (Ref: Negative) & -9.13 & $\begin{array}{l}-0.10 \\
(-0.59,0.40)\end{array}$ & 0.7005 \\
$\begin{array}{l}\text { No sample/missing } \\
\text { (Ref: Negative) }\end{array}$ & 8.38 & $\begin{array}{l}0.08 \\
(-0.44,0.60)\end{array}$ & 0.7586 \\
\hline
\end{tabular}

\section{Child PMTCT}

\begin{tabular}{llll} 
Yes (Ref: No) & 19.45 & $\begin{array}{l}0.18 \\
(-0.40,0.76)\end{array}$ & 0.5438 \\
\hline Unknown (Ref: No) & 8.92 & $\begin{array}{l}0.09 \\
(-1.09,1.26)\end{array}$ & 0.8856 \\
\hline & & &
\end{tabular}

\section{Mother PMTCT}

$\begin{array}{llll}\text { Yes (Ref: No) } & -5.09 & -0.05 & 0.8705 \\ & & (-0.69,0.58) & \end{array}$

\section{At week 84}

$\begin{array}{lllll}\log _{10} \text { anti-gp120 IgG } & 1.77 & 0.18 & 0.0612 & - \\ \text { (per 10\% increase) } & & (-0.01,0.36) & & \end{array}$

\section{HIV-1 serology}

$\begin{array}{lclllll}\text { Positive (Ref: Negative) } & 37.79 & \begin{array}{l}0.32 \\ (-0.10,0.74)\end{array} & 0.1298 & & \\ \begin{array}{l}\text { Not determined (Ref: } \\ \text { Negative) }\end{array} & 67.56 & \begin{array}{l}0.52 \\ (-0.22,1.25)\end{array} & 0.1654 & & \\ \begin{array}{l}\text { Duration of ART by } \\ \text { week 96 }\end{array} & -70.15 & \begin{array}{l}-1.21 \\ (-1.87,-0.55)\end{array} & 0.0004 & -70.14 & -1.21 & 0.0003 \\ \text { (per year longer) } & & & & & \\ \end{array}$

Note: Age at ART start was not fitted in the multivariable model due to multicollinearity with duration of ART by w96.

Key: $\beta$, regression coefficient estimates; $95 \% \mathrm{Cl}, 95 \%$ confidence interval of $\beta$; $\%$ change in HIV-1 DNA, a unit change in factors investigated is associated with a Y\% change in HIV-1 DNA, e.g. a month increase in age at ART start is associated with a $11.12 \%$ increase in HIV-1 DNA (univariable model).

b) Factors associated with HIV-1 DNA at week 248 
Univariable model

\% change $\quad b(95 \% \mathrm{Cl})$ in HIV

DNA
Multivariable model

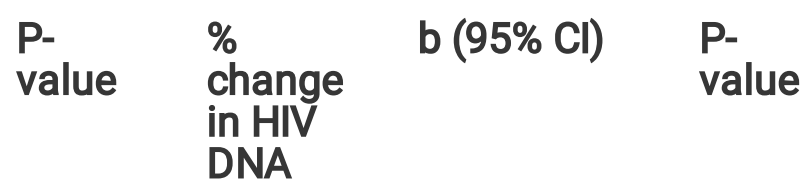

\section{At ART initiation}

Age (per month older)

1.16

0.01

0.4675

$\log _{10}$ viral load

1.42

$(-0.02,0.04)$

[copies/ml] (per 10\%

increase)

\section{Viral load}

$\begin{array}{llll}<750,000 \text { copies/ml (Ref: } & -15.38 & -0.17 & 0.3803 \\ \geq 750,000) & (-0.54,0.21) & \end{array}$

\begin{tabular}{lclc}
$\begin{array}{l}\text { Time to VL suppression } \\
\text { (per month longer) }\end{array}$ & 0.34 & $\begin{array}{l}0.00 \\
(-0.07,0.07)\end{array}$ & 0.9232 \\
$\begin{array}{l}\text { Birthweight (per Kg } \\
\text { higher) }\end{array}$ & -21.08 & $\begin{array}{l}-0.24 \\
(-0.62,0.15)\end{array}$ & 0.2283 \\
\hline
\end{tabular}

$\begin{array}{llll}\text { CD4 count (per } 500 \text { cell } & 4.93 & 0.05 & 0.3223 \\ \text { increase) } & (-0.05,0.14) & \end{array}$

$\begin{array}{llll}\text { CD4\% (per 10\% increase) } & 14.99 & 0.14 & 0.1505 \\ (-0.05,0.33) & \end{array}$

$\begin{array}{lllllll}\text { CD8 count (per } 500 \text { cell } & -5.20 & -0.05 & 0.1556 & -6.97 & -0.07 & 0.0398 \\ \text { increase) }\end{array}$

$\begin{array}{llllll}\text { CD8\% (per 10\% increase) } & -15.01 & -0.16 & 0.0489 & - & - \\ (-0.32,-0.00) & & & -\end{array}$

\section{Gender}

Male (Ref: Female)

$-21.86$

$-0.25$

$(-0.62,0.13)$

0.1940

\section{CDC stage}

$\begin{array}{llll}\text { A (Ref: N) } & -30.85 & -0.37 & 0.1286 \\ & & (-0.85,0.11) & \\ \text { B (Ref: N) } & -30.97 & -0.37 & 0.3567 \\ & & (-1.16,0.42) & \end{array}$

Ethnicity

Non-black (Ref: Black)

320.62

1.44

0.0010

$(0.59,2.29)$

Site 


\begin{tabular}{|c|c|c|c|c|c|c|}
\hline KIDCRU (Ref: PHRU) & -35.52 & $\begin{array}{l}-0.44 \\
(-0.81,-0.06)\end{array}$ & 0.0219 & -40.25 & $\begin{array}{l}-0.52 \\
(-0.85,-0.18)\end{array}$ & 0.0031 \\
\hline \multicolumn{7}{|l|}{ CMV Serology } \\
\hline Positive (Ref: Negative) & -19.03 & $\begin{array}{l}-0.21 \\
(-0.74,0.31)\end{array}$ & 0.4291 & & & \\
\hline $\begin{array}{l}\text { No sample/missing (Ref: } \\
\text { Negative) }\end{array}$ & 31.86 & $\begin{array}{l}0.28 \\
(-0.21,0.77)\end{array}$ & 0.2667 & & & \\
\hline \multicolumn{7}{|l|}{ Child PMTCT } \\
\hline Yes (Ref: No) & -39.28 & $\begin{array}{l}-0.50 \\
(-1.03,0.03)\end{array}$ & 0.0658 & - & - & - \\
\hline Unknown (Ref: No) & -25.04 & $\begin{array}{l}-0.29 \\
(-1.39,0.81)\end{array}$ & 0.6050 & - & - & - \\
\hline \multicolumn{7}{|l|}{ Mother PMTCT } \\
\hline Yes (Ref: No) & -13.90 & $\begin{array}{l}-0.15 \\
(-0.70,0.40)\end{array}$ & 0.5944 & & & \\
\hline \multicolumn{7}{|l|}{ At week 84} \\
\hline $\begin{array}{l}\log _{10} \text { anti-gp120 } \lg G \text { (per } \\
10 \% \text { increase) }\end{array}$ & 3.08 & $\begin{array}{l}0.31 \\
(0.07,0.55)\end{array}$ & 0.0131 & - & - & - \\
\hline \multicolumn{7}{|l|}{ HIV-1 serology } \\
\hline Positive (Ref: Negative) & 64.24 & $\begin{array}{l}0.50 \\
(-0.08,1.07)\end{array}$ & 0.0911 & 106.59 & $\begin{array}{l}0.73 \\
(0.23,1.22)\end{array}$ & 0.0042 \\
\hline $\begin{array}{l}\text { Not determined* (Ref: } \\
\text { Negative) }\end{array}$ & 60.24 & $\begin{array}{l}0.47 \\
(-0.09,1.03)\end{array}$ & 0.0981 & 90.99 & $\begin{array}{l}0.65 \\
(0.16,1.13)\end{array}$ & 0.0093 \\
\hline $\begin{array}{l}\text { Duration of ART by week } \\
\mathbf{2 4 8} \\
\text { (per year longer) }\end{array}$ & -36.27 & $\begin{array}{l}-0.45 \\
(-0.68,-0.22)\end{array}$ & 0.0002 & -30.01 & $\begin{array}{l}-0.36 \\
(-0.57,-0.15)\end{array}$ & 0.0011 \\
\hline $\begin{array}{l}\text { Duration of VL } \\
\text { suppression by week } 248 \\
\text { (per year longer) }\end{array}$ & -30.16 & $\begin{array}{l}-0.36 \\
(-0.53,-0.19)\end{array}$ & $\begin{array}{l}4.4 \mathrm{E}- \\
05\end{array}$ & - & - & - \\
\hline
\end{tabular}

Note: Duration of VL suppression by w248 was not fitted in the multivariable model due to multicollinearity with duration of ART by w248.

Key: $\beta$, regression coefficient estimates; $95 \% \mathrm{Cl}, 95 \%$ confidence interval of $\beta$; $\%$ change in HIV-1 DNA, a unit change in factors investigated is associated with a Y\% change in HIV-1 DNA, e.g. a year increase in duration of ART is associated with a $36.27 \%$ reduction in HIV-1 DNA (univariable model). *Not determined: these are samples not tested including ART-40W and some not tested in ART-Def and ART90W (see Table 3 for numbers). 
Figures

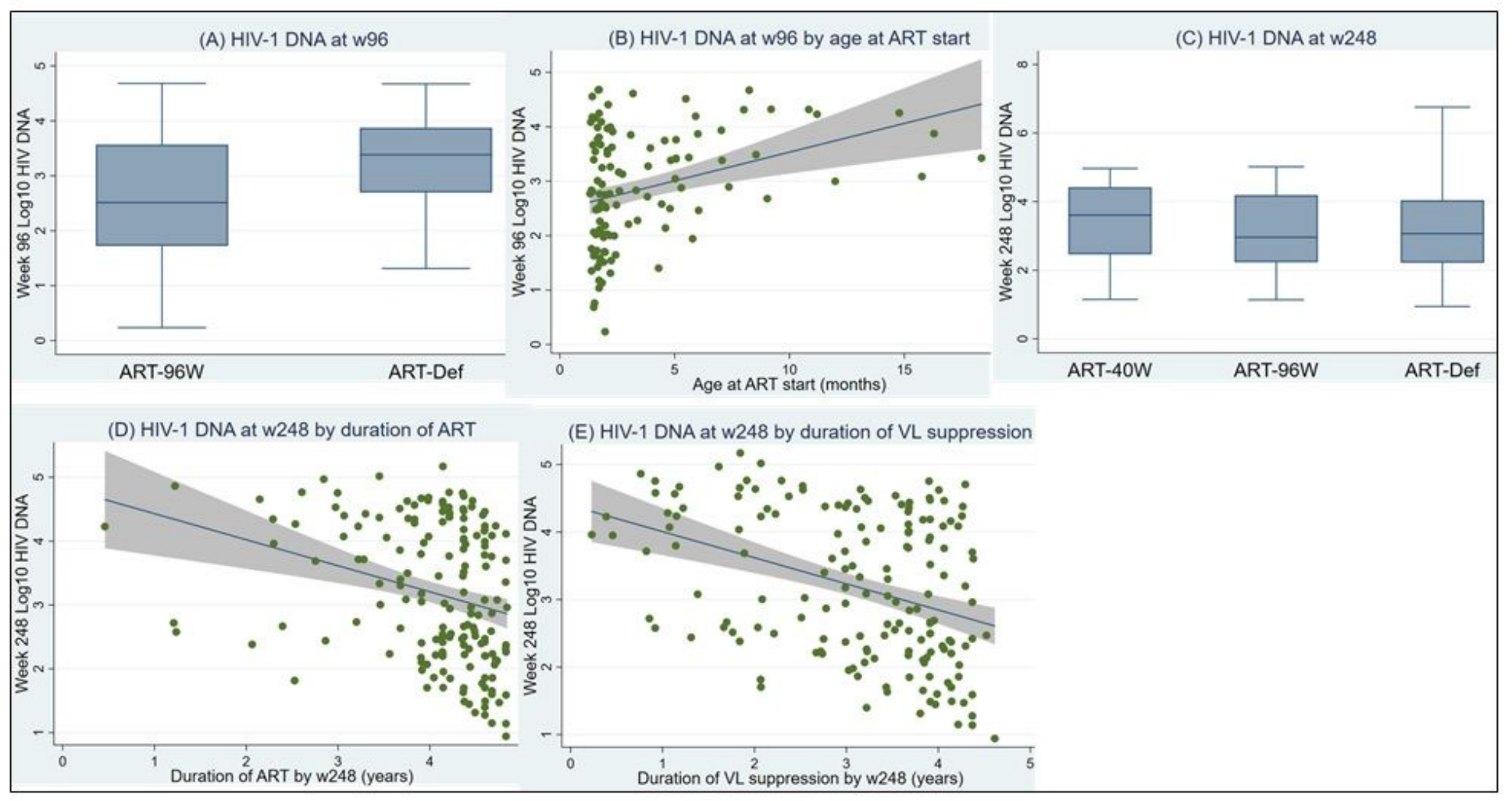

Figure 1

HIV-1 proviral DNA analysis from weeks 96 and 248 of the CHER trial. Y-axes represent HIV-1 proviral DNA (Log10 copies per 106 PBMCs). Plot A: HIV-1 proviral DNA in ART-Def ( $n=44$, median 2415 [IQR 4997450]) and ART-96W ( $n=73$, median (325 [53-3670] copies of HIV-1 proviral DNA/106 PBMCs]) at week 96 $(p=0.0019)$. Plot B: HIV-1 proviral DNA at week 96 by age of starting ART $(n=117)$. Plot C: HIV-1 proviral DNA in ART-Def $(n=70$, ART-40W $(n=56)$ and ART-96W $(n=43)$ at 248 weeks (Kruskal-Wallis test $\mathrm{p}=0.2553$ ). Plot D: HIV-1 proviral DNA at week 248 by duration of ART received by 248 weeks. Plot E: HIV1 proviral DNA at trial week 248 by weeks of continuous HIV-1 RNA suppression below 400 copies/ml. 